\title{
Aleksandra Kujawiak
}

Uniwersytet Łódzki

https://doi.org/10.18778/8142-463-9.05

\section{Kreatywność językowa a nazwy blogów parentingowych}

W ostatnich latach rosnącą popularnością cieszą się blogi, czyli „dzienniki, pamiętniki prowadzone w internecie, rodzaj osobistych stron WWW, na których autorzy umieszczają zapiski swoich bieżących przeżyć i przemyśleń oraz różne, ich zdaniem interesujące, informacje" [Kajtoch 2006: 18-19]. Dostarczają one internautom nie tylko rozrywki, ale przede wszystkim porad dotyczących tego, jak żyć, jak się ubierać, co jeść, czytać, oglądać, a wreszcie - jak wychowywać dzieci i dbać o nie już od pierwszych chwil życia. Ogromna rzesza czytelników każdego dnia śledzi codzienne życie autorów blogów parentingowych ${ }^{1}$, o czym świadczy stale zwiększająca się liczba stron o tej tematyce. Dla niektórych prowadzenie internetowego dziennika, w którym można dzielić się swoimi doświadczenia-

1 Sam przymiotnik parentingowy stanowi zapożyczenie $\mathrm{z}$ języka angielskiego i we współczesnej polszczyźnie - szczególnie internetowej - zastępuje wyrazy rodzicielski czy macierzyński. W założeniu ma odpowiadać tym aspektom bycia rodzicem, które wykraczają poza wymiar biologiczny; nawiązuje do dwóch koncepcji: rodzicielstwa bliskości (ang. attachment parenting) i tzw. rodzicielstwa powoli (ang. slow parenting). O popularności tego terminu pisze m.in. Jan Burzyński w ramach projektu Obserwatorium Językowe Uniwersytetu Warszawskiego [Burzyński 2016: 19]. 
mi, przemyśleniami i wątpliwościami, stało się sposobem na życie, a nawet źródłem utrzymania i zawodem [Kawka 2010: 65-66]. Nowym blogerom trudno jednak wyróżnić się wśród tak wielu stron dotyczących tej samej tematyki i mających swoich wiernych czytelników. Kluczem do zaistnienia w polskiej blogosferze parentingowej ${ }^{2}$ staje się zatem nazwa.

Jak każdy inny ideonim, tj. nazwa desygnująca wytwór artystyczny, nazwa bloga powinna spełniać funkcje: nominatywnąnazywać go, deskryptywną - charakteryzować jego tematykę i zawartość oraz pragmatyczną - wzbudzać zainteresowanie odbiorcy [Gajda 1987: 83-85]. W swoim artykule będę zwracała szczególną uwagę właśnie na tę ostatnią cechę, dlatego też obok klasyfikacji formalnej dokonam analizy semantycznej wyselekcjonowanego materiału. Dla blogera najważniejsze jest to, by stworzona przez niego nazwa była kreatywna - zaintrygowała odbiorcę do tego stopnia, by stał się czytelnikiem bloga, dlatego twórcy blogów parentingowych stosują różne zabiegi językowe, wśród których nie brakuje środków naruszających reguły językowe i estetyczne.

Przedmiotem mojej analizy będzie ponad sto nazw blogów parentingowych, które okazały się najpopularniejsze w styczniu 2017 roku według estymatora ruchu SimilarWeb.com ${ }^{3}$ i jego wskaźnika Total visits ${ }^{4}$. Dokonując analizy materiału, brałam pod uwage wyróżniony graficznie nagłówek bloga, najczęściej po odpowiedniej modyfikacji wchodzący w skład adresu WWW [Rutkowski, Skowronek 2004: 80-83]. Pomijam ewentualne podtytuły, które zazwyczaj stanowią doprecyzowanie gatunkowe, informując czy-

2 parentingowe.pl - strona zawiera posty, które ukazały się na blogach parentingowych w ciągu ostatniego tygodnia. Pomija się jednak blogi, które są nowe lub mało popularne.

3 SimilarWeb to portal internetowy, dzięki któremu można dokonać globalnej i lokalnej analizy ruchu na stronie internetowej pod kątem częstotliwości wizyt użytkowników.

4 Ranking ten został zamieszczony na jednym z blogów o tematyce parentingowej: https://www.szczesliva.pl/ranking-blogow-parentingowych-styczen-2017 (dostęp: 19.03.2018). 
telnika, że ma do czynienia z blogiem parentingowym albo krótko charakteryzują jego tematykę bądź ujawniają imię i nazwisko autora. Zachowuję oryginalną pisownię nazw, zwracając szczególną uwagę na te, które są pozbawione polskich znaków diakrytycznych.

Wśród wszystkich zgromadzonych nazw blogów można wskazać cztery grupy konstrukcji: werbalne, nominalne, swobodne, czyli przyimkowe, a także te, które nie podlegają bezpośredniej analizie, ponieważ są w języku angielskim. Zdecydowaną mniejszość stanowią nazwy werbalne w formie zdań oznajmujących: Róża marzy..., Kiedy mama nie śpi, Mama bloguje, pytających: Jak ona to robi, Czym zajać malucha? lub rozkazujących: Krystyno, nie denerwuj matki.

Największą grupę spośród wszystkich onimów stanowią konstrukcje nominalne, w obrębie których występują nazwy jedno-, dwu-i wielowyrazowe. W pierwszej grupie dominują przede wszystkim neologizmy słowotwórcze, czyli wyrazy utworzone od jakiejś podstawy słowotwórczej na gruncie języka polskiego [Sękowska 2012: 98]:

- Tekstualna - przymiotnik utworzony od rzeczownika tekst $\mathrm{z}$ formantem charakterystycznym dla przymiotników odczasownikowych -alna, konotującym zdolność, możliwość zrobienia czegoś [Grzegorczykowa 1979: 66-67]; w tym przypadku nazwa bloga zdaje się określać autorkę jako zdolną do tworzenia tekstów;

- Buuba - od neologizmu dziecięcego Buba oznaczającego imię Kuba;

- Nianio - neologizm dziecięcy od imienia syna blogerki Franio;

- Mamo!holiczka - połączenie leksemu mama z popularnym w najnowszym polskim słowotwórstwie sufiksoidem, konotującym osobę uzależnioną od czegoś - holik [Jadacka 2010: 43], dodatkowo wykrzyknik oddziela od siebie części nazwy, waloryzując człon inicjalny Mamo!;

- Wikilistka-deminutywna forma imienia Wiktoria (córki autorki) połączona z formantem -istka konotującym nazwy nosicieli cech;

- Olomanolo-neologizm od imienia Olek;

- Kreatywnik - neologizm, połączenie rzeczownika kreatywność i formantu-nik, charakterystycznego dla nazw narzędzi; 
- Mamala - kontaminacja leksemów mama i Ala (imię autorki bloga);

- Kosmetomama-złożenie powstałe wskutek połączenia podstaw słowotwórczych kosmet-i-mama interfiksem $o$.

Kolejną grupę nazw jednowyrazowych stanowią hybrydy językowe, które składają się z obcego wyrazu oraz polskiego elementu [Cyran 1974: 36]:

- Mamalife - polski leksem mama połączono z wyrazem z jęz. ang. life oznaczającym 'życie';

- Motheratorka - moderatorka to osoba, która kieruje dyskusją i czuwa nad jej właściwym przebiegiem, zwłaszcza w mediach; w tej nazwie zastosowano ciekawy zabieg słowny polegający na wprowadzeniu do polskiego zapisu angielskiego rzeczownika matka (mother);

- SimplyAnna - ang. 'po prostu Anna' - autorka na co dzień mieszka w Wielkiej Brytanii;

- Bizimummy - spolszczona wersja angielskiego przymiotnika busy (ang. zajęty) połączona z pieszczotliwą angielską formą rzeczownika mama - mummy (mamusia); ponadto autorka ma na imię Iza, więc może być to też forma gry językowej;

- Mamagerka - neologizm, kontaminacja leksemów mama i zapożyczonego z języka angielskiego leksemu: menadżer zachowującego oryginalną angielską pisownię (manager) z formantem - $k a$. W tej grupie pojawiają się też formy deminutywne, takie jak:

- Makóweczki-zdrobnienie od makówki;

- Wronek - od nazwiska autorki Wroniecka, pieszczotliwe określenie jej syna;

- Szafeczka-zdrobnienie od szafy.

Związane jest to zapewne z faktem, że tematyka blogów dotyczy głównie dzieci i zdrobnienia są tutaj naturalną formą wyrażania emocji związanych z rodzicielstwem, wychowywaniem potomstwa. Nie brakuje również skrótów utworzonych od kilku wyrazów i połączonych w całość, np. Mataja (mama, tata i ja) czy Tomitobi (od imion synów blogerki: Tomasza i Tobiasza). Autorzy blogów bardzo często wykorzystują nazwy własne, by nadać nazwie bloga jedyny 
i niepowtarzalny charakter. Są to głównie różnego rodzaju modyfikacje imion - własnych lub dzieci, nazwisk, ale także przezwisk czy wytworów języka dziecięcego, np. wyżej wspomniany blog Wronek (zdrobnienie od nazwiska syna autorki - Wroniecki), Kamperki - zdrobnienie od pseudonimu taty „Kamper”, Hafija - zmodyfikowana forma ukraińskiego odpowiednika imienia autorki bloga Agaty (Ahafiya), Ronja - strona Reni Hannoleinen o życiu w stylu skandynawskim nawiązuje do tytułu znanej powieści dla dzieci Astrid Lindgren Ronja, córka zbójnika. Wśród nazw blogów pojawiają się też oryginalne imiona, będące wytworami samych autorów, np. Nishka czy Segritta. Blogerzy często podkreślają - jak Segritta ${ }^{5}$ - że nazwa jest ich własnością intelektualną chronioną prawem autorskim. Przestrzegają czytelników przed jej kopiowaniem i używaniem w celach marketingowych.

$\mathrm{W}$ analizowanym materiale widać ponadto tendencję do tworzenia onimów na wzór makrotoponimów, np. Tosinkowo, Bakusiowo. Ostatnia nazwa przyciąga uwagę odbiorcy, gdyż jej wyjaśnienie nie jest oczywiste dla osób, które nie są czytelnikami strony. Bakusiowo - to rodzinny, pełen harmonii świat wykreowany przez autorkę bloga Malwinę Bakalarz (Bakuś - forma deminutywna od nazwiska). Nieoczywista i zagadkowa nazwa może zatem stanowić zachętę dla internautów, by zapoznali się z treścią strony. Niektórzy blogerzy sięgają także po niebanalne połączenia już istniejących wyrazów, np. Szalonooka, Piwnooka, czy ich modyfikacje, np. Szczesliva - pozbawiony polskich znaków diakrytycznych przymiotnikszczęśliwa, dodatkowo z pisownią $v$ zamiast $w$, charakterystyczną dla języka angielskiego. Ze względu na tematykę poruszaną na blogach pojawiają się też nazwy nawiązujące do teorii pedagogicznych, jak np. Nebule ${ }^{6}$ - zaczerpnię-

5 Segritta - Matylda Kozakiewicz, autorka bloga segritta.pl oraz książki Zte matki sa najlepsze (Poradnik szczęśliwej mamy).

6 Autorka bloga - Anna Trawka, z wykształcenia pedagog i terapeuta, wyjaśnia swoim czytelnikom, co oznacza nazwa Nebule: „Wg M. Montessori są to wrodzone zdolności, gotowość do opanowania nowych umiejętności, np. mowy, ruchu” - https://www.nebule.pl/koniec-liliija [dostęp: 15.03.2018]. 
te $\mathrm{z}$ teorii Marii Montessori czy po prostu wskazujące na poruszane przez autora problemy, np. Trojaczki-blog o tematyce bliskiej rodzicom, którzy mają mnogie potomstwo, Oczekując-strona poświęcona ciąży, okresowi oczekiwania na narodziny dziecka.

Drugą liczną grupę konstrukcji nominalnych stanowią nazwy dwuwyrazowe, wśród których można wyodrębnić następujące podtypy:

- rzeczownik z przydawką przymiotną: Nieperfekcyjna mama, Mamine skarby, Maluszkowe inspiracje, Jaśkowe klimaty, Matczyne fanaberie, Rodzinne porachunki, Zabiegana mama, Stodki ciężar, Matka nieidealna, Mama kreatywna, Mama Biznesowa, Budujacca mama, Kreatywnym Okiem;

- rzeczownik z przydawką mianownikową: Blog Ojciec, Zuch.Media, Siostra Ania, Matka Wariatka, Basia Szmydt, Julia Rozumek;

- rzeczownik z przydawką dopełniaczową: Mama Kubusia, Matka Prezesa, Mama Carla, Ojca Raj, Pamiętnik Mamy, Mama Trójki, Mamy Gadizety;

- inne: Okiem mamy.

W tej grupie zdecydowanie przeważają nazwy, w których członem dominującym jest leksem mama/matka, a pozostała część tytułu stanowi jego przydawkowe uzupełnienie. Powtarzają się dwa schematy: - mama/matka - jaka? - nieperfekcyjna, nieidealna, zabiegana, wariatka;

- mama - czyja? - Kubusia, Prezesa, Carla.

Pojawiają się również derywaty, np. mamine, matczyne. Warto zwrócić uwagę, że w przypadku blogów parentingowych prowadzonych przez mężczyzn już w nazwie bloga podkreśla się punkt widzenia ojca (Ojca Raj, Blog Ojciec).

W obrębie konstrukcji nominalnych stosunkowo rzadko pojawiają się nazwy wielowyrazowe, wśród których trudno jest wskazać schemat budowy. Są to konstrukcje typu: rzeczownik + przymiotnik + rzeczownik: Noszki-Domowa Manufaktura, przymiotnik + rzeczownik + przymiotnik: Kreatywne prace plastyczne, zaimek + rzeczownik + przysłówek: Moje dzieci kreatywnie, rzeczownik + spójnik + rzeczownik: Olga i Okolice. 
Obok konstrukcji werbalnych i nominalnych występują także nazwy zawierające wyrażenia przyimkowe. Choć jest ich niewiele, można zauważyć zdecydowaną dominację leksemu mama: Mama $w$ biegu, Mama na tropie, Mama w UK, Mama w domu, Tylko dla mam. Ciekawą propozycją jest nazwa Na kolkach zamiast wyrażenia przyimkowego na kótkach, co jest oczywistym nawiązaniem do problemów powszechnych wśród niemowląt i zaintryguje każdego rodzica, którego dziecko miewa podobne dolegliwości.

Na uwagę zasługuje fakt, iż wiele spośród blogów o tematyce rodzicielskiej pisanych w języku polskim, zawierających treści dotyczące realiów życia w Polsce, posiada w pełni angielskie nazwy. Nie są to hybrydy językowe, jak: Mamalife czy wzorowana na angielskiej pisowni nazwa Motheratorka, ale zupełnie obcobrzmiące: Oh deer!, Cover baby, Lady of the house, Mum and the city ${ }^{7}$, Flow Mummy. Nadmiar zapożyczeń może wynikać nie tylko z mody językowej czy atrakcyjniejszego brzmienia nazwy angielskiej, lecz także z dostępności określonego adresu WWW.

Analiza zebranego materiału wykazała, że wśród nazw blogów parentingowych dominują nazwy jedno-i dwuwyrazowe. Odbiorca otrzymuje zatem krótką i zwięzłą informację o tym, jaka jest treść strony. Funkcję deskryptywną w największym stopniu realizują te nazwy, które zawierają leksemy mama, ojciec lub ich derywaty (Mamo!holiczka, Mama bloguje, Matka Wariatka, Mamy Gadzety, Mama Kubusia, Matka Prezesa, Mama Biznesowa, Mama Trójki, Pamiętnik Mamy, Okiem Mamy, Nieperfekcyjna mama, Mamine Skarby, Budujaca mama, Matczyne fanaberie, Matka nieidealna, Mama kreatywna, Mamagerka, Mamowato, Kosmetomama, Mama w biegu, Mama na tropie, Matka tylko jedna, W roli mamy, Mamaw UK, Zabiegana mama, Ojca Raj, Blog Ojciec). Pozwala to na rozpoznanie intencji autora - potencjalny czytelnik od razu wie, że na tej stronie znajdzie porady związane z wychowywaniem dziecka, być może rozwieje swoje wątpliwości, podzieli się własnymi doświadczeniami z innymi rodzicami.

7 Nazwa bloga nawiązuje także do angielskiego tytułu popularnego serialu Seks w wielkim mieście (ang. Sex and the city). 
Bardzo często w nazwach blogów parentingowych wykorzystuje się nazwy własne - najczęściej są to zmodyfikowane imiona, rzadziej nazwiska lub pseudonimy autorów (Buuba, Wikilistka, Nianio, Basia Szmydt, Julia Rozumek, Mama Kubusia, Tosinkowo, Hafija, Nishka, Wronek, Kamperki, Ronja, Mamala, Olomonolo, Segritta, Bakusiowo). Stanowi to wyraz typowej dla komunikacji internetowej orientacji blogera na siebie [Suska 2013: 81]. Dodatkowo formy deminutywne sprawiają, że czytelnik odbiera autora bloga jako kochającego rodzica, podobnego do niego samego, a przez to mu bliskiego. Nierzadko lektura bloga prowadzi do zawierania znajomości internetowych oraz wymiany poglądów na portalach społecznościowych, takich jak Facebook, Twitter czy Instagram.

Ogromną frekwencję mają nazwy, które realizują funkcję pragmatyczną, przyciągając uwagę odbiorcy grą słów i znaczeń albo obco brzmiącą konstrukcją językową. Do tej grupy należą przede wszystkim neologizmy - słowotwórcze: Buuba, Nianio, Mamo!holiczka, Wikilistka, Olomanolo, Kreatywnik, Mamala, Kosmetomama, Mamagerka, Mamowato. Szczególną uwagę zwraca nazwa Mamagerka, będąca kontaminacją leksemów mamai menag $(d \dot{z})$ erka, co stanowi waloryzację roli matki jako tej, która „zarządza” rodziną, czyli swoistym przedsiębiorstwem. Wzbudza to u odbiorcy-matki zdecydowanie pozytywne emocje - czuje się ważna, doceniana, czego często może brakować kobietom zajmującym się domem, rezygnującym z pracy zawodowej lub pozostającym na urlopie macierzyńskim. Podobny mechanizm psychologiczny widać w nazwie Motheratorka, będącej hybrydą językową i jednocześnie kontaminacją powstałą w wyniku połączenia słów moderatorka i ang. mother ('matka'). W tym przypadku oryginalna angielska pisownia ma zaintrygować odbiorcę, zwrócićjego uwagę, a jednocześnie podkreślić rolę matki w funkcjonowaniu całej rodziny. Anglicyzmy są szczególnie preferowane przez autorów blogów parentingowych: Mrs. Polka Dot, Mamalife, Lady of the house, Oh deer!, Lady Gugu ${ }^{8}$, Cover baby, Bizi-

8 Nazwa stanowi grę językową z odbiorcą - nawiązuje do pseudonimu artystycznego piosenkarki, Lady Gagi, i jednocześnie wykorzystuje neologizm dziecięcy: gugu. 
mummy, SimplyAnna, Mum and the city. Może to wynikać $\mathrm{z}$ faktu, że język angielski stał się współczesnym lingua franca i zapanowała moda na używanie anglicyzmów nawet wtedy, gdy nie ma potrzeby zastępowania rodzimych leksemów obcymi. Podobnie jak samo pojęcie parenting, które choć ma swój odpowiednik w języku polskim ('rodzicielski', 'wychowawczy'), weszło na stałe do internetowego języka blogosfery. Dla niektórych odbiorców zapożyczenia z języka angielskiego pełnią funkcję nobilitującą, wydają się atrakcyjniejsze. Przykładem może być chociażby Mamalife zamiast polskiego określenia, np. 'Życie matki'.

Blogerzy są świadomi tego, że jako „prowadzący internetowy dziennik” powinni tworzyć takie nazwy, które przyciągną uwagę odbiorcy. Kreatywność jest także cechą szczególnie cenną dla każdego rodzica, który na co dzień stara się być pomysłowy i oryginalny, by sprostać wymaganiom dzieci. Być może dlatego wśród analizowanych nazw znajdują się i takie, które bezpośrednio odwołują się właśnie do tej cechy: Kreatywne prace plastyczne, Kreatywnik, Moje dzieci kreatywnie, Kreatywnym Okiem, Mama Kreatywna.

\section{Bibliografia}

Bendyk E. [2007], Blogosfera, [w:] E. Chudziński (red.), Stownik wiedzy o mediach, Wydawnictwo Szkolne PWN, Bielsko-Biała.

Burzyński J. [2016], Stownik języka nowego. Rodzicielstwo albo parenting, „Uniwersytet Warszawski”, nr 1, http://nowewyrazy.uw.edu.pl/plikizew/gazeta-uw_1_2016.pdf(dostęp: 15.03.2018).

Cyran W. [1974], Mechanizm zapożyczania wyrazów w języku polskim, „Rozprawy Komisji Językowej ŁTN”, t. XX, s. 24-36.

Gajda S. [1987], Społeczne determinacje nazw własnych tekstów (tytułów), „Socjolingwistyka”, nr 6, s. 79-89.

Grzegorczykowa R. [1979], Zarysstowotwórstwa polskiego, PWN, Warszawa. Jadacka H. [2010], Neologizmy jako przedmiot opisu lingwistycznego: na marginesie pracy E. Worbs, A. Markowskiego, A. Megera "Polnisch-deutsches Wörterbuch der Neologismen. Neuer polnischer Wortschatz nach 1989”, „LingVaria”, nr 1, s. 39-52. 
Kajtoch W. [2006], Blog, [w:] W. Pisarek (red.), Stownik terminologii medialnej, Universitas, Kraków.

Kawka M. [2010], Blog jako gatunek dziennikarski-ewolucja i transgresja, [w:] K. Wolny-Zmorzyński (red.), Internetowe gatunki dziennikarskie, Wydawnictwa Akademickie i Profesjonalne, Warszawa.

Sękowska E. [2012], Neologizmy stowotwórcze we wspólczesnej polszczyźnie (wybrane tendencje), „Eslavística Complutense”, nr 12, s. 97-103.

Skowronek K., Rutkowski M. [2004], Media i nazwy, Lexis, Kraków.

Suska D. [2013], Językowe właściwości nazw blogów kulinarnych, „Prace Naukowe Akademii im. J. Długosza w Częstochowie”, z. IX, s. 73-84. Wiśniewska-Białas H. [2011], Wpływ języka angielskiego na polszczyznę blogów, Wydawnictwa Uniwersytetu Warszawskiego, Warszawa.

\section{Strony internetowe}

http://nebule.pl (dostęp: 15.03.2018).

http://parentingowe.pl (dostęp: 15.03.2018).

http://segritta.pl (dostęp: 15.03.2018).

http://sjp.pwn.pl (dostęp: 15.03.2018).

http://szczesliva.pl (dostęp: 15.03.2018). 